\title{
Application of heterogeneous catalytic ozonation process for treatment of high toxic effluent from a pesticide manufacturing plant
}

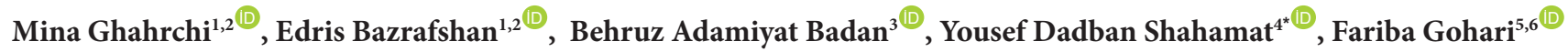 \\ ${ }^{1}$ Department of Environmental Health Engineering, School of Health, Torbat Heydariyeh University of Medical Sciences, Torbat \\ Heydariyeh, Iran \\ ${ }^{2}$ Health Sciences Research Center, Torbat Heydariyeh University of Medical Sciences, Torbat Heydariyeh, Iran \\ ${ }^{3}$ Lamei Gorgani Institute of Higher Education, Gorgan, Iran \\ ${ }^{4}$ Environmental Health Research Center, Department of Environmental Health Engineering, Faculty of Health, Golestan University of \\ Medical Sciences, Golestan, Iran \\ ${ }^{5}$ Department of Environmental Health Engineering, School of Health, Golestan University of Medical Sciences, Gorgan, Iran \\ ${ }^{6}$ Department of Civil and Environmental Engineering, University of Western Ontario, London, Canada
}

\begin{abstract}
Background: The discharge of untreated wastewater containing toxic and resistant compounds into the environment is a serious threat for ecosystems. Therefore, this study was conducted to evaluate the treatment of poison production factory wastewater using heterogeneous catalytic ozonation process (COP). Methods: Magnetic carbon nanocomposite was used as a catalyst at concentrations of 1,2, and $4 \mathrm{~g} / \mathrm{L}$. Its effect on improving the treatment process was evaluated at reaction time of 30, 60, 90, and 120 minutes. At the end of each experiment, parameters including total organic carbon (TOC), chemical oxygen demand (COD), biological oxygen demand $\left(\mathrm{BOD}_{5}\right), \mathrm{pH}$, electrical conductivity $(\mathrm{EC})$, and turbidity were measured. Results: It was revealed that in single ozonation process (SOP), the maximum removal efficiencies of TOC, $\mathrm{COD}$, and $\mathrm{BOD}_{5}$ were achieved at reaction time of 120 minutes as $56 \%, 40 \%$, and $11.7 \%$, respectively. By adding the catalyst to the wastewater, the treatment process was improved, so that the maximum removal efficiencies of $\mathrm{COD}(91 \%)$, TOC $(73 \%)$, and $\mathrm{BOD}_{5}(74 \%)$ were obtained at catalyst concentration of $4 \mathrm{~g} / \mathrm{L}$. Under this condition, $\mathrm{BOD}_{5} / \mathrm{COD}$ ratio increased from 0.22 to 0.64 . Also, the results of analysis of ozone consumption per each $\mathrm{mg}$ of reduced COD showed that its amount sharply decreased from $2.1 \mathrm{mgO}_{3}$ I $\mathrm{mg}$ COD removal in the SOP, to $0.34 \mathrm{mgO}_{3} / \mathrm{mg} \mathrm{COD}$ removal in the COP. The results of kinetic reaction analysis also revealed that the rate constant increased from 0.007 to $0.02 \mathrm{~min}^{-1}$.

Conclusion: According to the results, it can be concluded that the COP at a catalyst concentration of $4 \mathrm{~g} / \mathrm{L}$, by decomposing resistant compounds and increasing the biodegradability, can be used as a suitable pretreatment method for biological processes.

Keywords: Wastewater, Treatment, Nanocomposite, Catalytic ozonation, Kinetics

Citation: Ghahrchi M, Bazrafshan E, Adamiyat Badan B, Dadban Shahamat Y, Gohari F. Application of heterogeneous catalytic ozonation process for treatment of high toxic effluent from a pesticide manufacturing plant. Environmental Health Engineering and Management Journal 2020; 7(2): 79-88. doi: 10.34172/EHEM.2020.10.
\end{abstract}

\section{Article History:} Received: 16 February 2020 Accepted: 2 May 2020 ePublished: 15 May 2020

\section{Introduction}

Nowadays, with increasing resistant compounds in industrial wastewater, more stringent environmental regulations, inefficiency of conventional treatment methods for removal of such pollutants to achieve desirable standards are among the main problems of wastewater treatment industry, which require more research for finding new and effective methods to remove the pollutants (1).
Pesticide manufacturing industry is categorized as one of the industries, which its wastewater contains resistant and recalcitrant compounds, such as confidor, paraquat, glyphosate, and abamectin. The discharge of wastewater containing such toxins into water resources leads to surface and groundwater pollution and endangers public health $(2,3)$.

Confidor or imidacloprid $\left(\mathrm{C}_{9} \mathrm{H}_{10} \mathrm{ClN}_{5} \mathrm{O}_{2}\right)$ is a systemic insecticide, which is widely used to control many 
agricultural pests. The United States Environmental Protection Agency (USEPA) has determined the permissible concentration of confidor in surface water and groundwater about $36.04 \mathrm{ppb}$ and $2.09 \mathrm{ppm}$, respectively. Paraquat $\left(\mathrm{C}_{12} \mathrm{H}_{14} \mathrm{Cl}_{2} \mathrm{~N}_{2}\right)$ and glyphosate $\left(\mathrm{C}_{3} \mathrm{H}_{8} \mathrm{NO}_{5} \mathrm{P}\right)$ are applicable to control weeds, which act non-selectively. As the solubility of paraquat in water is high, contamination of water resources and damage to aquatic organisms are highly likely. Also, damage to the kidneys, liver, and lungs has been reported by this herbicide (4). Another herbicide, glyphosate, was classified by the World Health Organization (WHO) in 2015 as a carcinogenic compound for humans (5). So far, no guidelines have been put in place for the residual glyphosate and paraquat in water resources, however, the European Union (EU) has determined the limited value for each type of herbicide in drinking water as $0.1 \mu \mathrm{g} / \mathrm{L}(6)$. Abamectin with chemical formula of $\mathrm{C}_{48} \mathrm{H}_{72} \mathrm{O}_{14}\left(\mathrm{~B}_{1} \mathrm{a}\right)$ and $\mathrm{C}_{47} \mathrm{H}_{70} \mathrm{O}_{14}\left(\mathrm{~B}_{1} \mathrm{~b}\right)$, is an insecticide that has contact and digestive properties, as well as a gradual effect on pests, however, its crippling effect occurs quickly. The amount of LD50 for rats is 10 $\mathrm{mg} / \mathrm{kg}$. According to a research on rats, the exposure to $0.40 \mathrm{mg} / \mathrm{kg} /$ day of abamectin, increases stillbirths, and decreases pup viability, lactation, and pup weights (7). There are several methods for removal of pesticides, but the most commonly used methods are thermal absorption, membrane processes, contaminated soil washing, biological removal, and chemical and electrochemical processes, each of which has its own advantages and disadvantages (8). For example, absorption methods and membrane processes can be effective in removing poisons from wastewater, but they have also some disadvantages such as absorbent loss, incomplete treatment, high system cost, while it requires revival. Also, biological treatment is not suitable for treatment of wastewater containing pesticides and insecticides, which have a polycyclic structure and resistant, because the treatment is incomplete and sludge disposal is difficult. Therefore, due to the recalcitrant and resistant structure of poison compounds, the use of oxidation methods to degrade these pollutants are preferred today. So far, several studies have been done in this field. Dridi Gargouri et al investigated the efficacy of electrochemical oxidation process to remove dimethoate insecticides with $\mathrm{PbO}_{2}$ electrode, and reported $90 \%$ chemical oxygen demand (COD) removal efficiency at a current density of $50 \mathrm{~mA} /$ $\mathrm{cm}^{2}$ after 8 hours of reaction time (9). Hachami et al investigated electrochemical oxidation of methidathion as an organophosphorus pesticide by $\mathrm{SnO}_{2}$ and borondoped diamond (BDD) anodes. They reported that COD removal efficiencies under conditions of $2 \% \mathrm{NaCl}, 60 \mathrm{~mA} /$ $\mathrm{cm}^{2}$ current density, and 120 minutes reaction time, using $\mathrm{SnO}_{2}$ and $\mathrm{BDD}$ electrodes, were $73 \%$ and $85 \%$, respectively (10). However, the expensive nature of the electrodes and the complex operation of the system are the limits for using these methods on a larger scale.
Recently, newer methods, such as the use of ultrasonic waves and advanced oxidation technologies, such as plasma, Fenton, photo-Fenton, wet oxidation by peroxide, ozonation, and photocatalytic processes such as $\mathrm{O}_{3} / \mathrm{UV}$, have been used for the treatment of industrial wastewater. But, these methods due to complex operation and high cost of treatment in field are not attractive processes $(8,11,12)$.

Advanced oxidation processes (AOPs) are methods that act based on the production of free radicals of hydroxyl, which have high ability to decompose various organic materials.

Today, in the AOPs, homogeneous or heterogeneous catalysts are used to remove non-biodegradable compounds, which in most cases, the toxicity of pollutants is very high. So that, they are mostly used as a pretreatment for biological treatment process. The effect of AOPs depends on the treatment conditions including: $\mathrm{pH}$, temperature, and concentration of the reactants $(13,14)$. Catalytic ozonation process (COP) is one of the AOPs that utilizes catalysts. With the decomposition of ozone molecule, hydroxyl radicals are produced, which are stronger oxidizing agents than ozone (15). In single ozonation process (SOP), decomposition of toxic substances is usually not complete and effective. Furthermore, most of the intermediates produced are more toxic and non-degradable. However, the COP can overcome this limitation (16). In the COP, if soluble metal ions, such as $\mathrm{Fe}^{2+}, \mathrm{Cu}^{2+}, \mathrm{Mn}^{2+}, \mathrm{Co}^{2+}$ are used as catalysts, the process is homogeneous catalytic ozonation and if insoluble metal oxides and other insoluble compounds are used, this process is called heterogeneous catalytic ozonation, which $\mathrm{AC}, \mathrm{Fe}_{2} \mathrm{O}_{3}, \mathrm{MnO}_{2}, \mathrm{CuO}, \mathrm{Fe}_{3} \mathrm{O}_{4} / \mathrm{CoO}$, $\mathrm{Cu} / \mathrm{ZrO}_{2}, \mathrm{Mn} / \mathrm{TiO}_{2}$, and $\mathrm{Al}_{2} \mathrm{O}_{3}$ are of these kinds of catalysts (17). In a study by Maddila et al, heterogeneous photocatalytic ozonation of bromoxynil pesticide using Cs-doped bare $\mathrm{TiO}_{2}$ as photocatalyst was investigated. They found that after 2 hours reaction time, $100 \%$ of the pesticide was decomposed (18). Mosleh and Rahimi used the combination of ultrasonic cavitation and $\mathrm{Cu}_{2}(\mathrm{OH}) \mathrm{PO}_{4}$-HKUST-1 MOF as a visible-light driven photocatalyst for degradation of abamectin pesticide. They reported that under optimum conditions this process is capable of destroying $99.93 \%$ of abamectin in 20 minutes reaction time (19). In another study by Pourzad et al, the mineralization of paraquat by visible light-induced photocatalytic degradation using N-doped TiO2@SiO2@ $\mathrm{Fe} 3 \mathrm{O} 4$ nanocomposite was investigated. They reported the maximum total organic carbon (TOC) removal efficiency by this process as $84.71 \%$ (4). In general, despite the high efficiency of the mentioned processes, the toxicity of some catalysts such as $\mathrm{TiO} 2$ for human body, the difficulty of the process operation and its high cost are the main disadvantages of these processes $(20,21)$.

Activated carbon (AC) is one of the catalysts that has attracted the attention of majority of researchers. Since 
ozone oxidizes the absorbed material in $\mathrm{AC}$, and on the other hand, AC itself can act as a catalyst to decompose ozone into hydroxyl radicals, simultaneous application of $\mathrm{AC}$ and ozone can increase the removal efficiency of pollutants $(16,22,23)$.

Another advantages of using AC as a catalyst include ineffectiveness of temperature in the process performance, lower consumption and optimal use of ozone, ineffectiveness of radical scavenger factors such as bicarbonate, which is a major contributing factor in the AOPs, as well as the lack of influence of $\mathrm{pH}$ (24). One of the disadvantages of the AC powder application, is its separation after the reaction and the possibility of its recovery and return to the system $(25,26)$. By adding magnetic iron nanoparticles, superparamagnetic particles or magnetic AC lead to the synergistic effect of catalyst and its easy recycling for repeated use, which can resolve the problems of recycling and effectiveness of the catalysts and also improve the removal efficiency of pollutants (26). In this study, the COP using modified $\mathrm{AC}$ with $\mathrm{Fe}_{3} \mathrm{O}_{4}$ nanoparticles was used to treat real wastewater of pesticide manufacturing plant. In this method, in addition to the possibility of application on a higher scale, the limitations of other methods, such as the complexity of the operation, high cost and toxicity of the catalysts, as well as the existence of the catalyst in the effluent have been improved. However, so far this method has not been used for treatment of extremely toxic wastewater.

\section{Materials and Methods}

\section{Characteristics of wastewater}

The wastewater under study was prepared from a pesticide manufacturing plant in Gorgan city. Characteristics of the wastewater samples collected including the amounts of poisons (confidor, paraquat, glyphosites, and abamectin) and minor amounts of other possible pesticides, are shown in Table 1.

\section{Characteristics of catalyst}

The catalyst used in the COP, was a nanocomposite made of $\mathrm{AC}$ modified by $\mathrm{Fe}_{3} \mathrm{O}_{4}$ via impregnation method, which its characteristics is thoroughly studied and mentioned in previous studies. Also, according to the results of these studies, $\mathrm{pHzpc}$ was 7.7 and natural $\mathrm{pH}$ of the wastewater was about 7 , therefore, it was considered as the optimum $\mathrm{pH}$ and all experiments were performed at this $\mathrm{pH}(16,27)$.

\section{Chemicals}

Potassium dichromate $\left(\mathrm{K}_{2} \mathrm{Cr}_{2} \mathrm{O}_{7}\right)$, sulfuric acid $\left(\mathrm{H}_{2} \mathrm{SO}_{4}\right)$, mercuric sulfate $\left(\mathrm{HgSO}_{4}\right)$, silver sulfate $\left(\mathrm{Ag}_{2} \mathrm{SO}_{4}\right)$, potassium hydrogen phthalate $\left(\mathrm{HOOCC}_{6} \mathrm{H}_{4} \mathrm{COOK}\right)$, potassium iodide (KI), ferrous chloride tetrahydrate $\left(\mathrm{FeCl}_{2}, 4 \mathrm{H}_{2} \mathrm{O}\right)$, ferric chloride hexahydrate $\left(\mathrm{FeCl}_{3}, 6 \mathrm{H}_{2} \mathrm{O}\right)$, ammonia $\left(\mathrm{NH}_{3}\right)$, and powdered $\mathrm{AC}(\mathrm{PAC})$ were purchased with analytical purity from Merck Company (Germany).

\section{The COP and SOP processes}

A cylindrical reactor was used to treat the wastewater using the SOP and COP. The height and inside diameter of the reactor were 100 and $5 \mathrm{~cm}$, respectively, that in each experiment, $250 \mathrm{~mL}$ of the wastewater was transferred to the reactor for the treatment process. Since the reactor was designed as a Semi-Batch system, ozone gas with concentration of $33 \mathrm{mg} / \mathrm{min}$ entered from the bottom of the reactor through a ceramic bed stone and the wastewater influent was continuously introduced to the batch reactor. The air stream containing ozone gas after contacting with the solution, exited from the top of the reactor and excessive ozone gas was trapped in two impingers containing potassium iodine (20\%), and consequently, removed from the system.

The schematic of the reactor is shown in Figure 1. Ozone gas was generated from pure oxygen via corona discharge (99.9\%) and an ozone generator (Aryoun Tabriz Company, Iran) manufactured in France, with capacity of $5 \mathrm{gO}_{3} / \mathrm{h}$. The inlet flow of ozone was adjusted by a rotameter (with capacity of $3.5 \mathrm{~L} / \mathrm{min}$ ) to a value of $0.5 \mathrm{~L} / \mathrm{min}$.

\section{Analyses method}

At the end of each experiment, some of the treated effluent was taken to determine the concentrations of TOC, COD, and biological oxygen demand $\left(\mathrm{BOD}_{5}\right)$, as well as $\mathrm{pH}$, electrical conductivity (EC) $(\mathrm{HACH}, \mathrm{HQ} 40 \mathrm{~d}$ model), and turbidity (HACH, 2100Q model). Samples were taken from both discharge valves and mixed for homogenization. The TOC concentration was measured by a TOC analyzer device (Jena 3100, Germany) based on the NPOC (Non-Purgeable Organic Carbon) program with a temperature program including combustion chamber at $800^{\circ} \mathrm{C}$, Peltier temperature of $10^{\circ} \mathrm{C}$, and the flux of oxygen gas was equal to 5 logs per $200 \mathrm{~mL} / \mathrm{min}$. The COD concentration was determined using Closed Reflux method (5220D) according to "Standard Methods for the Examination of Water and Wastewater" book by a spectrophotometer (HACH, DR5000 model, Germany) at a wavelength of $600 \mathrm{~nm}$ (28).

Then COD removal efficiency was calculated based on Eq. (1):

COD removal efficiency $(\%)=\left[\left(C O D_{0}-C O D_{t}\right) / C_{0}\right] \times 100(1)$

Where, $C O D_{0}$ and $C O D_{t}$ are the initial concentration

Table 1. Characteristics of the pesticide manufacturing plant wastewater

\begin{tabular}{lcccccc}
\hline Parameter & TOC $(\mathrm{mg} / \mathrm{L})$ & $\mathrm{COD}(\mathrm{mg} / \mathrm{L})$ & BOD $_{5}(\mathrm{mg} / \mathrm{L})$ & $\mathrm{pH}$ & Turbidity $(\mathrm{NTU})$ & $\mathrm{EC}(\boldsymbol{\mu s} / \mathrm{cm})$ \\
\hline Value & 977.5 & 3888 & 1333.3 & 6.88 & 242 & 484 \\
\hline
\end{tabular}




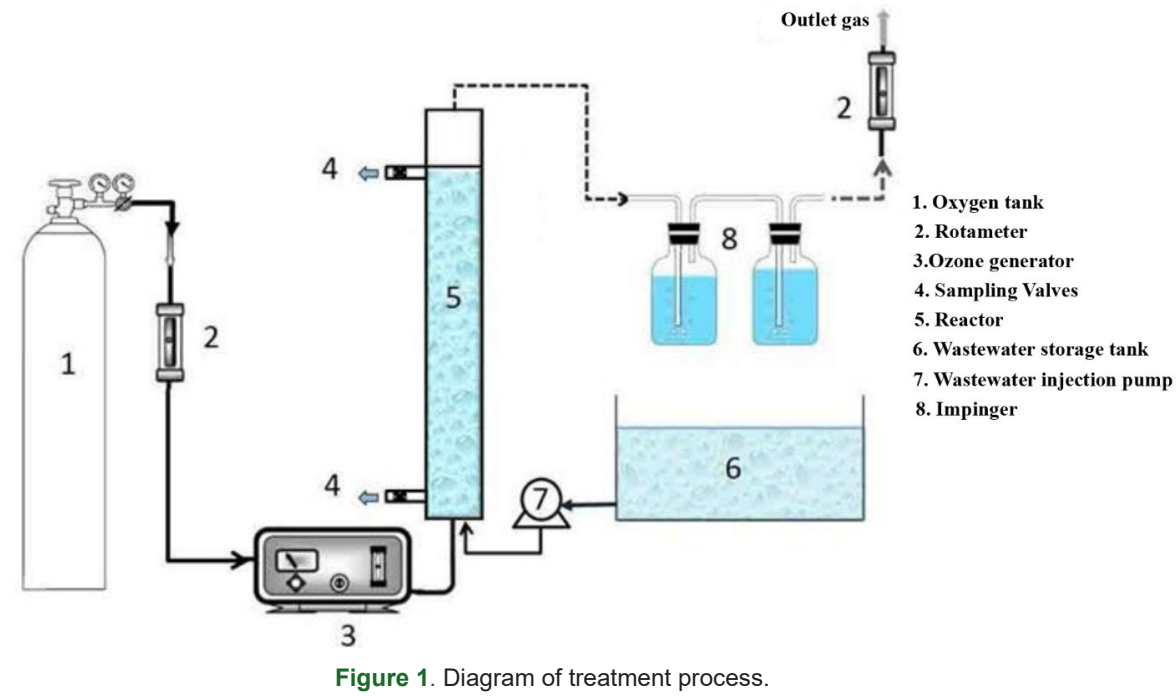

of COD and the concentration of COD at any time $(\mathrm{t})$ $(\mathrm{mg} / \mathrm{L})$, respectively.

To determine the amount of biodegradable organic matter, the concentration of $\mathrm{BOD}_{5}$ was measured using barometric method.

The ozone concentration in the inlet and outlet of the reactor was measured according to Method 2350E (KI) $(29,30)$. Also, ozone consumption for COD reduction was calculated according to Eq. (2):

Ozone Consumption (OC, $\left.m g O_{3} / m g C O D\right)=\frac{Q_{G}}{V} \frac{\int_{0}^{t}\left(C_{A G 0} / C_{A G}\right) d t}{C O D_{0}-C O D_{t}}(2)$

Where $Q_{\mathrm{G}}, V, C_{\mathrm{AG}}, C_{\mathrm{AG},}$, and $t$ are gas flow rate $(\mathrm{L} / \mathrm{min})$, liquid volume $(\mathrm{L})$, off-gas ozone concentration $(\mathrm{mg} / \mathrm{L})$, input ozone concentration $(\mathrm{mg} / \mathrm{L})$, and time, respectively (31).

Finally, the following first-order kinetic model was used to determine the pollutant removal reaction rate as Eq. (3):

$\operatorname{Ln} \frac{\mathrm{C}_{\mathrm{t}}}{\mathrm{C}_{0}}=-\mathrm{K}_{1} \mathrm{t}$

Where $C_{t}$ and $C_{0}$ are the COD concentration at reaction time of $t$ and $t_{0}$, respectively, and $K_{1}$ is the reaction rate constant (32).

\section{Results}

In this study, the wastewater containing various pesticides, such as confidor, paraquat, glyphosites, and abamectin was treated under the SOP and COP.

In the COP, the effect of different concentrations of catalysts $(1,2$, and $4 \mathrm{~g} / \mathrm{L})$ on the treatment process improvement was investigated by measuring the amounts of $\mathrm{COD}, \mathrm{TOC}, \mathrm{BOD}_{5}, \mathrm{pH}, \mathrm{EC}$, turbidity, and ozone consumption. Also, the kinetic reactions for each process were calculated and evaluated. The results obtained from each parameter are discussed further in the following sections.
Performance of the SOP and COP for TOC and COD reduction

At the end of each experiment, the concentration of TOC and COD were measured and the amounts of TOC/TOC and $\mathrm{COD} / \mathrm{COD}_{0}$ were calculated, and the results are shown in Figure 2. According to this figure, the amounts of TOC/TOC and $\mathrm{COD} / \mathrm{COD}_{0}$ in the SOP with injection of $33 \mathrm{mg} / \mathrm{min}$ ozone decreased during the reaction time, so that the minimum amounts of these parameters achieved at reaction time of 120 minutes, were about 0.59 and 0.43 , respectively. However, by adding different concentrations of the catalyst $(1,2$, and $4 \mathrm{~g} / \mathrm{L})$ in the COP, the reduction of the TOC and COD concentration, were considerably enhanced, which at catalyst concentration of $4 \mathrm{~g} / \mathrm{L}$, after 120 minutes of reaction time, the minimum amounts of TOC/TOC 0 and $\mathrm{COD} / \mathrm{COD}_{0}$ were obtained to be about 0.23 and 0.08 , respectively.

Mineralization and evaluation of $\mathrm{pH}, \mathrm{EC}$, and turbidity In the present study, by measuring TOC, the mineralization of these complex organic compounds and their decomposition by the SOP and COP were investigated. The results of the TOC removal efficiency are shown in Figure 3. As shown in this figure, in both SOP and COP, TOC removal efficiency increased over time, so that the amount of this parameter in the SOP at reaction times of $30,60,90$, and 120 minutes were obtained as $24 \%, 33 \%$, $39 \%$, and $40 \%$, respectively. In return, in the COP, with addition of a catalyst in the presence of ozone, the TOC concentration was significantly reduced and with regard to the nonselective characteristic of hydroxyl radicals, the rate of the TOC removal efficiency increased over time. Among different concentrations of catalyst $(1,2$, and $4 \mathrm{mg} / \mathrm{L})$, the best performance of the COP was at concentration of 4 $\mathrm{mg} / \mathrm{L}$. In this condition, the maximum TOC removal efficiency $(73 \%)$ was obtained at 120 minutes. In addition to removal efficiency of TOC, the amount of $\mathrm{pH}, \mathrm{EC}$, and turbidity of the effluent were measured, and the results are 


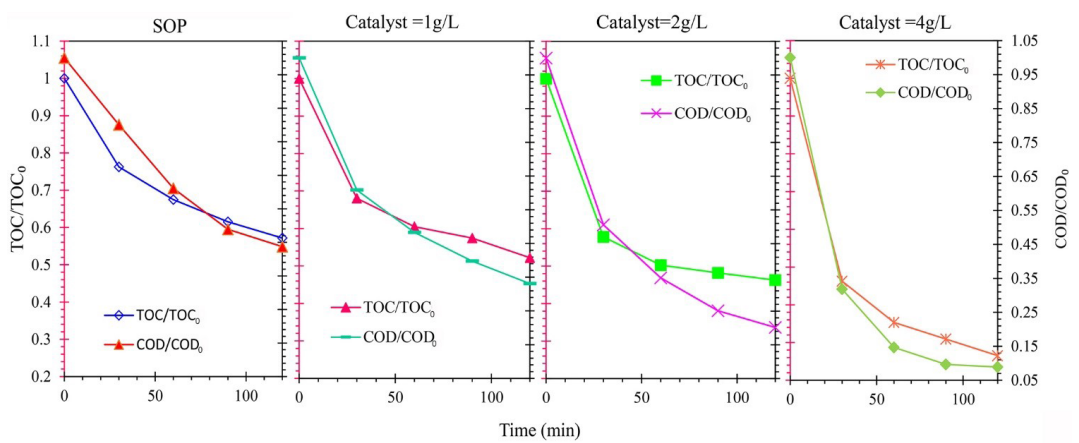

Figure 2. Effect of catalyst concentration on the TOC/TOC and $C O D / \mathrm{COD}_{0}$ values at different times (pH: 6.88, EC: $484 \mu \mathrm{S} / \mathrm{cm}$, turbidity: $242 \mathrm{NTU}$ ).

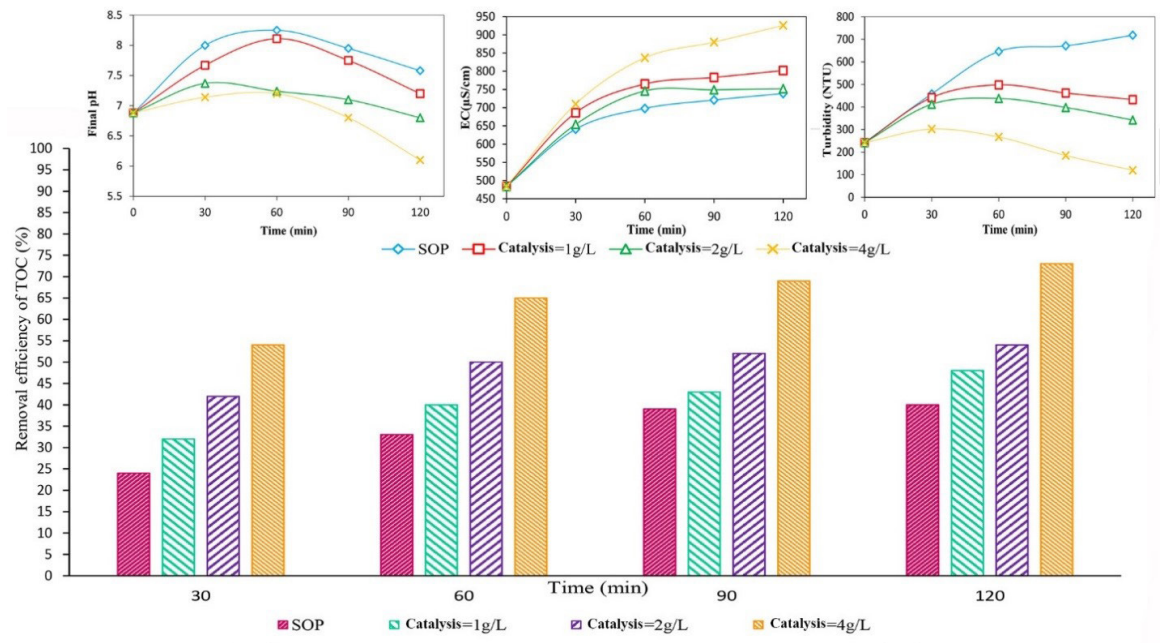

Figure 3. Effect of catalyst concentration on the TOC removal efficiency, pH, EC, and turbidity of effluent at different times (pH: 6.88 , EC: $484 \mu \mathrm{S} / \mathrm{cm}$, turbidity: 242 NTU).

shown in Figure 3. Evaluation of the final $\mathrm{pH}$ in the COP indicates an increase in its values in the first hours. In the SOP, the effluent $\mathrm{pH}$ was almost neutral, whereas in the COP, especially at the maximum catalyst concentration, $\mathrm{pH}$ of the effluent was acidified. As can be seen in Figure 3, in the SOP, EC increased from 484 to $739 \mu \mathrm{S} / \mathrm{cm}$, however, in the COP, this increase was more significant. The values of this parameter, at 120 minutes of reaction time and at catalyst concentrations of 1,2 , and $4 \mathrm{mg} / \mathrm{L}$ were 752,802 and $926 \mu \mathrm{S} / \mathrm{cm}$, respectively. Turbidity of effluent was another parameter that was tested in each experiment. The results showed that turbidity in the SOP increased over time. Also, in the COP, at catalyst concentrations of 1 and $2 \mathrm{~g} / \mathrm{L}$, the values of this parameter during the first hour were ascending. But, at catalyst concentration of $4 \mathrm{~g} / \mathrm{L}$, the wastewater turbidity, with a relative increase in the first minutes, after 2 hours of reaction time was decreased to about 120 NTU.

Ozone consumption

As mentioned earlier, ozone consumption in the reactor was measured using Eq. (2). The amount of ozone consumption per $\mathrm{mg} / \mathrm{L}$ of COD removed was calculated and the results are shown in Table 2 . As shown in this table, the amount of ozone consumption in the SOP at reaction time of $30,60,90$, and 120 minutes were $1.54,1.74,1.81$, and $2.1 \mathrm{mg} / \mathrm{L}$ per $\mathrm{mg} / \mathrm{L}$ removal of COD, respectively. By adding the catalyst in the COP, a decreasing trend was seen for these values and at concentration of $4 \mathrm{~g} / \mathrm{L}$ and reaction time of 120 minutes, the minimum ozone consumption was obtained to be $0.34 \mathrm{mg} \mathrm{O}_{3} / \mathrm{mg} \mathrm{COD}$.

\section{Biodegradability}

In this study, BOD5/COD of raw wastewater was 0.22 , indicating the low biodegradability of its nature. However, by performing the SOP and COP, the values of this index for treated effluent were improved and the results are

Table 2. The effect of catalyst concentration on ozone consumption per COD removal ( $\mathrm{mg} \mathrm{O} / \mathrm{mg}$ COD reduction)

\begin{tabular}{lcccc}
\hline \multirow{2}{*}{ Process } & \multicolumn{4}{c}{ Time $(\mathrm{min})$} \\
\cline { 2 - 5 } & $\mathbf{3 0}$ & $\mathbf{6 0}$ & $\mathbf{9 0}$ & $\mathbf{1 2 0}$ \\
\hline SOP, Catalyst $=0 \mathrm{~g} / \mathrm{L}$ & 1.54 & 1.74 & 1.81 & 2.1 \\
$\mathrm{COP}$, Catalyst $=1 \mathrm{~g} / \mathrm{L}$ & 1.3 & 0.87 & 0.78 & 0.76 \\
$\mathrm{COP}$, Catalyst $=2 \mathrm{~g} / \mathrm{L}$ & 0.82 & 0.69 & 0.62 & 0.61 \\
COP, Catalyst $=4 \mathrm{~g} / \mathrm{L}$ & 0.59 & 0.43 & 0.39 & 0.34 \\
\hline
\end{tabular}


shown in Figure 4. According to the findings, $\mathrm{BOD}_{5} / \mathrm{COD}$ increased in the both processes. The maximum amount of $\mathrm{BOD}_{5} / \mathrm{COD}$ in the SOP, after 120 minutes of reaction time was equal to 0.51 . The concentration of $\mathrm{BOD}_{5}$ under this condition was $867 \mathrm{mg} / \mathrm{L}$, which was more than the primary concentration of $\mathrm{BOD}_{5}$. In the $\mathrm{COP}$, by increasing the amount of catalyst and reaction time, $\mathrm{BOD}_{5}$ concentration was decreased, and consequently, led to an increase in $\mathrm{BOD}_{5} / \mathrm{COD}$. At catalyst concentrations of 1,2 , and $4 \mathrm{~g} / \mathrm{L}$ and reaction time of 120 minutes, $\mathrm{BOD}_{5}$ values were 610,453 , and $220.8 \mathrm{mg} / \mathrm{L}$ and the ratio of $\mathrm{BOD}_{5} /$ COD were $0.47,0.57$, and 0.64 , respectively.

\section{Kinetic study}

To understand the rate of oxidation reactions by each of the SOP and COP, the reaction kinetics were calculated based on the pseudo-first-order kinetic (Eq. 3.), and the obtained results are shown in Figure 5. The minimum amount of constant velocity (k) was obtained in the SOP, but by adding catalyst, this constant increased, so that at catalyst concentration of $4 \mathrm{~g} / \mathrm{L}$, the maximum value of $\mathrm{K}$ was obtained to be about $0.02 \mathrm{~min}^{-1}$.

\section{Discussion}

The findings showed that the performance of the COP was better than that of the SOP in reducing the COD and TOC concentration from the pesticide manufacturing plant wastewater. In the SOP, ozone acts through direct and indirect oxidation to degrade and remove pollutants (21). In direct oxidation, ozone molecule directly enters the reaction with organic matter and oxidizes it, this mechanism occurs more in acidic $\mathrm{pH}$ (33). But indirect ozone oxidation, which is usually carried out in alkaline conditions, leads to the decomposition of ozone and production of radical hydroxyl. According to Eqs. (4 and 5), these radicals react with contaminant molecules that contain different toxins and degrade substances into simpler compounds (16).

$\mathrm{O}_{3}+\mathrm{H}_{2} \mathrm{O} \rightarrow 2 \mathrm{HO}_{2}$

$\mathrm{O} 3+\mathrm{HO}_{2} \rightarrow \mathrm{HO} \cdot+2 \mathrm{O}_{2}$

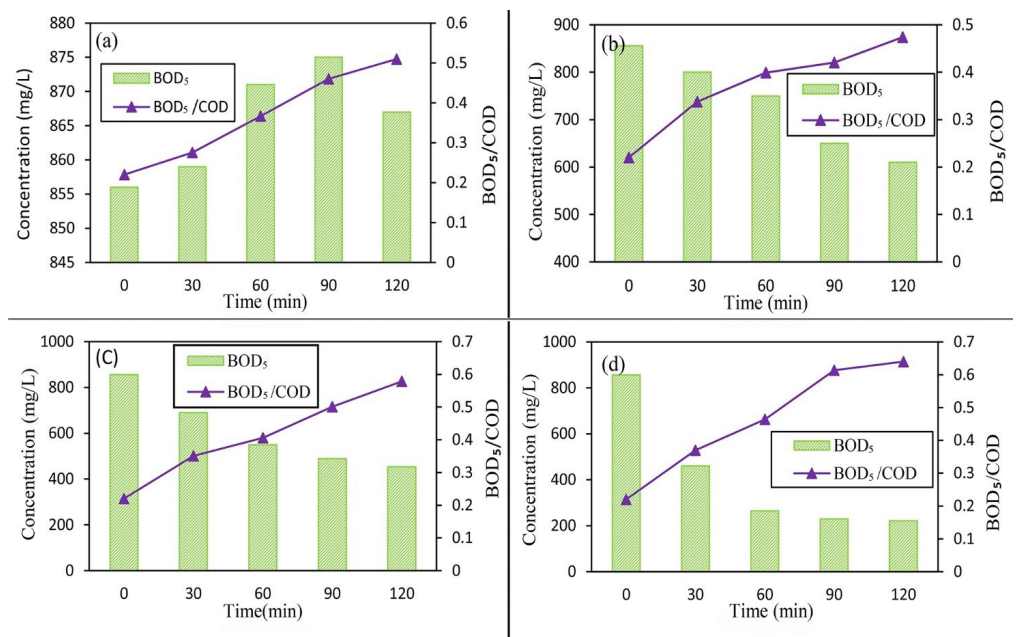

Figure 4. Effect of catalyst concentration on the concentration of BOD5 and biodegradability at different times. (a): SOP, Catalyst $=0 \mathrm{~g} / \mathrm{L}$, (b): COP, Catalyst $=1 \mathrm{~g} / \mathrm{L},(\mathrm{c}): \mathrm{COP}$, Catalyst $=2 \mathrm{~g} / \mathrm{L},(\mathrm{d}): \mathrm{COP}$, Catalyst $=4 \mathrm{~g} / \mathrm{L}(\mathrm{pH}: 6.88, \mathrm{EC}: 484 \mu \mathrm{S} / \mathrm{cm}$, turbidity: $242 \mathrm{NTU})$.

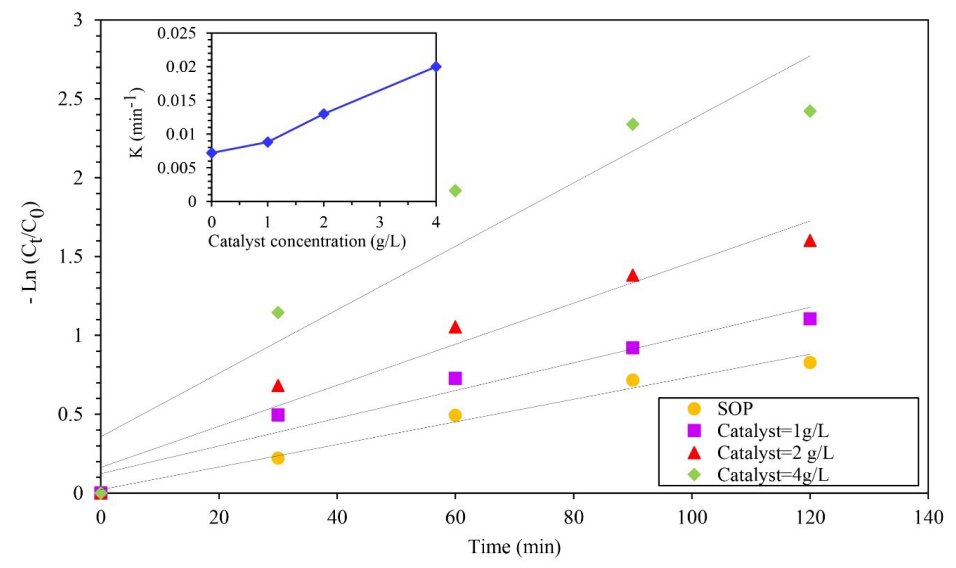

Figure 5. Kinetic information of COD reduction and rate constant as a function of catalyst concentration in the SOP and COP (pH: $6.88, E C: 484 \mu \mathrm{S} / \mathrm{cm}$, turbidity: 242 NTU). 
Application of ozone alone has limitations, such as high energy consumption, selectivity, and lack of complete mineralization of pollutants especially for resistant compounds. In contrast, the COP which acts through ozone decomposition by catalysts and hydroxyl radical production, does not have the limitations of the SOP. One of the catalysts used in the COP is AC, which in combination with ozone, the limitation of adsorption capacity and active sites of this adsorbent has been improved $(34,35)$. According to the results of other studies, the reaction of ozone with active carbon in the presence of organic compounds is calculated using following Eqs. (611) $(36,37)$ :

$\mathrm{TOC}_{0}+\mathrm{AC} \leftrightarrow \mathrm{TOC}_{0}-\mathrm{AC}$

$\mathrm{O}_{3}+\mathrm{AC} \leftrightarrow \mathrm{O}_{3}-\mathrm{AC}$

$\mathrm{TOC}_{0}-\mathrm{AC}+\mathrm{O}_{3}-\mathrm{AC} \rightarrow \mathrm{TOC}+\mathrm{H}_{2} \mathrm{O}_{2}$

$\mathrm{H}_{2} \mathrm{O}_{2}+\mathrm{AC} \leftrightarrow \mathrm{H}_{2} \mathrm{O}_{2}-\mathrm{AC}$

$\mathrm{H}_{2} \mathrm{O}_{2}-\mathrm{AC}+\mathrm{O}_{3}-\mathrm{AC} \rightarrow \mathrm{HO}+\mathrm{AC}$

$\mathrm{TOC}_{0}+\mathrm{HO} \cdot \rightarrow \mathrm{TOC}+\mathrm{HO}_{2}$.

AC modification can increase function groups at the catalyst surface to react with ozone. In this study, the $\mathrm{AC}$ was modified with $\mathrm{Fe}_{3} \mathrm{O}_{4}$ nanoparticles, which act as a catalyst in the COP. According to the results of other studies, production of radical hydroxyl and degradation of contaminants in this process can be done through the following mechanisms $(25,38,39)$ :

- Ozone adsorption by functional groups at the catalysts surface including AC modified with $\mathrm{Fe}_{3} \mathrm{O}_{4}$

- Decomposition of ozone molecule and production of strong radical species such as hydroxyl radical

These radicals are strong oxidizers, which can be very effective in decomposing recalcitrant and toxic compounds.

So far, several studies have been conducted on the application of COP to remove various pollutants from wastewater, in all of which superiority of this process has been confirmed in comparison with the SOP. Wu et al compared the efficiency of the SOP and COP in removal of phenolic compounds in the presence of $\mathrm{AC}$ and $\mathrm{Mn}$ / $\mathrm{AC}$ catalysts. In this research, they found that in the COP, the constant amount of decomposition (k) for phenolic compounds was much higher than that in the SOP. Also, this constant for AC/Mn catalyst was higher than that for AC alone (40). Fan et al, investigated the degradation of atrazine toxicity by the SOP and COP using multi-walled carbon nanotubes as a catalyst, and concluded that the COP leads to further reduction in wastewater toxicity and increase in atrazine mineralization (41). In another study, Akhtar et al investigated the removal of sulfamethoxazole from wastewater by combined adsorption and COP using $\mathrm{Fe}_{2} \mathrm{O}_{3} / \mathrm{CeO}_{2}$ and $\mathrm{AC}$, and reported that at absorbent concentration of $2 \mathrm{~g} / \mathrm{L}$ and contact time of 70 minutes, the removal efficiency was promoted from about $37 \%$ in the SOP to $86 \%$ in the COP. The reason for this increase was mentioned to be the production of more radical hydroxyl as a result of ozone decomposition (42).

In this study, increasing the catalyst concentration improved the COP performance in reducing the ratio of $\mathrm{COD} / \mathrm{COD}_{0}$ and $\mathrm{TOC} / \mathrm{TOC}_{0}$. Generally, by increasing the catalyst concentration, the catalyst surface area and active sites are expanded, and subsequently, improves the adsorption-catalytic oxidation process by increasing the absorption of pollutants on the catalyst surface area, decomposition of ozone and production of more active oxidizing species. However, in the COP, the function of catalyst at different concentrations is affected by several factors including the conditions of the catalyst reaction, the type of catalyst, the characteristics of target pollutant, and the amount of efficiency required (21). Hence, in the present study, a catalyst concentration of $4 \mathrm{mg} / \mathrm{L}$ was considered as the optimal value. Similar results were reported by other studies that have used the COP to remove resistant contaminants $(43,44)$.

As mentioned before, the wastewater under treatment contained various pesticides including confidor, paraquat, glyphosites, and abamectin. These pesticides are aromatic compounds with benzene rings. By ozone injection, these toxins are oxidized and converted into simpler compounds with shorter chains. But, as shown in Figure 3 , in the SOP, the rate of mineralization was almost stable after 90 minutes of reaction time. In fact, at the onset of the SOP, the concentration of compounds that are easily oxidized by ozone is higher. With increasing time, the concentration of these compounds decreased and the SOP efficiency for mineralization of organic compound did not increase significantly (33). But, in the COP, the hydroxyl radicals produced during the process, acted as non-selective and performed complete mineralization of complex compounds, which is consistent with the results of a study by Trapido et al (45). Other studies have shown that some of the intermediate compounds produced during the oxidation process include $4.4^{\prime}$-bipyridine, monopyridone, 4-picolinic acid, and hydroxyl-4-picolinic acid. By continuing the reaction of radical hydroxyl with these compounds, the long chains were oxidized to shorter chains and became simpler carboxylic acids including oxalic, acetic, formic, and succinic acids (46).

By considering the results of the effluent $\mathrm{pH}$ changes, this result can be understood. In the $\mathrm{COP}, \mathrm{pH}$ increased in the first 60 minutes. This increase is due to the characteristics of the catalyst and the presence of functional groups on its surface, which leads to an increase in $\mathrm{pH}$, however, after this time, $\mathrm{pH}$ decreased (16). Due to the oxidation of organic compounds by the SOP and especially the COP and production of simpler intermediates such as carboxylic acids, the $\mathrm{pH}$ reduction is justifiable and lower final $\mathrm{pH}$ in the $\mathrm{COP}$, can be attributed to the improved performance of the process in decomposition of organic contaminants. Hu et al, treated the industrial wastewater containing resistant compounds using COP, in which 
carbon aerogel was used as a catalyst. They reported a decrease in the effluent $\mathrm{pH}$ and it can be due to the generation of acidic intermediate compounds (47), which is consistent with the results of other studies $(42,48)$. Increasing $\mathrm{EC}$ of the wastewater over time also confirms these results. In fact, the oxidation of larger organic compounds during the SOP and COP and formation of simpler compounds and ions, lead to an increase in EC. However, it should be noted that the EC values in the COP, especially at a catalyst concentration of $4 \mathrm{~g} / \mathrm{L}$, were higher than those in the SOP. In a study by Ghahrchi et al, ozonation and electro-catalytic ozonation of toxic and recalcitrant compounds in mature landfill leachate were performed and it was found that the mineralization of complex compounds leads to an increase in EC and this increase is more noticeable in the electro-COP (49). These results indicate better performance of the COP in the mineralization of contaminants through the generation of radical hydroxyl, which is consistent with the results of several studies (50-52). The turbidity of the effluent was another parameter, which was investigated in this study. The increase of turbidity can be due to the formation of intermediate compounds and turbulence caused by ozone injection. However, in the COP, by adding $4 \mathrm{~g} / \mathrm{L}$ of the catalyst, the mineralization of the compounds in the wastewater was completed and this limitation was improved.

The reduction in the amount of ozone consumption was another advantage of the COP, which its value was related improving the efficiency of COD removal in COP leads to reduced amount of ozone consumption. The amount of ozone consumption is very important in terms of economic and energy consumption. Pocostales et al also reported that in the COP, ozone consumption is significantly reduced for removal of certain amounts of pharmaceutical compounds from wastewater (8). Biodegradability of wastewater is determined by calculating the $\mathrm{BOD}_{5} / \mathrm{COD}$ ratio. Usually, for wastewater with $\mathrm{BOD}_{5} / \mathrm{COD}$ ratio less than 0.3 , biological methods are not effective. The AOP processes such as COP not only oxidize pollutants in the wastewater, but also increase biodegradability and reduce wastewater toxicity.

To describe this fact, it should be noted that oxidation and degradation of larger organic compounds into smaller molecules and incomplete mineralization of organic compounds by ozone can lead to an increase in the $\mathrm{BOD}_{5}$ concentration. Therefore, the main reason for the increase in the $\mathrm{BOD}_{5} / \mathrm{COD}$ ratio was the increase in the $\mathrm{BOD}_{5}$ concentration, and the decrease of COD amount was not significant. The results obtained in other studies to improve the biodegradability of wastewater confirms the results of this study $(49,53)$.

But, in the COP, the hydroxyl radical production and complete mineralization of organic compounds by these radicals led to a reduction in the concentration of $\mathrm{BOD}_{5}$ and significantly COD, which increases the biodegradability of wastewater containing toxins. As shown in Figure 5, it can be concluded that the COP performance is clearly better than the SOP performance in treatment of wastewater. Also, higher amounts of velocity constant in the COP confirm the higher speed of oxidation process in removal of contaminants.

\section{Conclusion}

In this study, the treatment of pesticide manufacturing plant wastewater by heterogeneous catalytic ozonation using carbonaceous nanocomposite was investigated. These catalysts in the presence of ozone, produce hydroxyl radical as a strong oxidant, which results in an effective removal of contaminants. Furthermore, due to its magnetic properties, it is easy to collect this catalyst from effluent. The optimum condition was obtained at catalyst concentration of $4 \mathrm{~g} / \mathrm{L}$ and reaction time of 120 minutes, under which the ratios of $\mathrm{TOC} / \mathrm{TOC}_{0}$ and $\mathrm{COD} / \mathrm{COD}_{0}$ were reduced to 0.26 and 0.088 , respectively. But, in the $\mathrm{SOP}$, the ratios of $\mathrm{TOC} / \mathrm{TOC}_{0}$ and $\mathrm{COD} / \mathrm{COD}_{0}$ were about 0.599 and 0.43 , respectively. During oxidation of organic compounds in the SOP and COP, $\mathrm{pH}$ was decreased. Although $\mathrm{pH}$ decline in the SOP was not significant, but at catalyst concentration of $4 \mathrm{~g} / \mathrm{L}$ in the COP, the effluent $\mathrm{pH}$ became so acidic. The amount of EC at catalyst concentrations of $0,1,2$, and $4 \mathrm{~g} / \mathrm{L}$ and reaction time of $120 \mathrm{~min}$ were $739,752,802$, and $906 \mu \mathrm{S} / \mathrm{cm}$, respectively, and the amounts of turbidity were obtained to be 718,433 , 342 , and 120 NTU, respectively. The EC increase indicates mineralization and degradation of larger and more stable organic molecules, which consequently, increases biodegradability. In the COP, at catalyst concentration of 4 $\mathrm{g} / \mathrm{L}$, ozone consumption for COD removal is significantly reduced. Production of hydroxyl radicals in the COP as a result of ozone reaction with catalyst increased oxidation process, the process efficiency, as well as the oxidation rate of the pollutants. Given that the effluent sample in this study was real, the results can be used directly in wastewater treatment produced in the poison manufacturing industry and similar industries. In order to complete the results of this project in the future, the ozone consumption momentarily for consumed TOC can be measured by stoichiometry of the ozone reaction.

\section{Acknowledgements}

Authors would like to appreciate Golestan University of Medical Sciences for providing financial and instrumental support to conduct this work.

\section{Ethical issues}

The authors certify that this manuscript is the original work of the authors, all data collected during the study are presented in this manuscript, and no data from the study has been or will be published elsewhere separately (Ethical Number: IR.GOUMS.REC.1396.14). 


\section{Competing interests}

The authors declare that they have no conflict of interests.

\section{Author's contributions}

All authors contributed equally and participated in the data collection, analysis, and interpretation. They also critically reviewed, refined, and approved the manuscript.

\section{References}

1. Dehghani MH, Sarmadi M, Alipour MR, Sanaei D, Abdolmaleki $\mathrm{H}$, Agarwal $\mathrm{S}$, et al. Investigating the equilibrium and adsorption kinetics for the removal of $\mathrm{Ni}$ (II) ions from aqueous solutions using adsorbents prepared from the modified waste newspapers: a low-cost and available adsorbent. Microchem J 2019; 146: 1043-53. doi: 10.1016/j.microc.2019.02.042.

2. Santos Mónica SF, Alves A, Madeira LM. Paraquat removal from water by oxidation with Fenton's reagent. Chem Eng J 2011; 175: 279-90. doi: 10.1016/j.cej.2011.09.106.

3. Vymazal J, Březinová T. The use of constructed wetlands for removal of pesticides from agricultural runoff and drainage: a review. Environ Int 2015; 75: 11-20. doi: 10.1016/j.envint.2014.10.026.

4. Pourzad A, Sobhi HR, Behbahani M, Esrafili A, Kalantary RR, Kermani M. Efficient visible light-induced photocatalytic removal of paraquat using N-doped TiO2@ SiO2@Fe3O4 nanocomposite. J Mol Liq 2020; 299: 112167. doi: $\quad 10.1016 /$ j.molliq.2019.112167.

5. Rubí-Juárez $\mathrm{H}$, Cotillas $\mathrm{S}$, Sáez C, Cañizares P, BarreraDíaz C, Rodrigo MA. Removal of herbicide glyphosate by conductive-diamond electrochemical oxidation. Appl Catal B Environ 2016; 188: 305-12. doi: 10.1016/j. apcatb.2016.02.006

6. Hu YS, Zhao YQ, Sorohan B. Removal of glyphosate from aqueous environment by adsorption using water industrial residual. Desalination 2011; 271(1-3): 150-6. doi: 10.1016/j. desal.2010.12.014

7. Ghalwa A, Nasser M, Farhat NB. Removal of abamectin pesticide by electrocoagulation process using stainless steel and iron electrodes. J Environ Anal Chem 2015; 2(3): 134. doi: 10.4172/2380-2391.1000134.

8. Pocostales P, Álvarez P, Beltrán FJ. Catalytic ozonation promoted by alumina-based catalysts for the removal of some pharmaceutical compounds from water. Chem Eng J 2011; 168(3): 1289-95. doi: 10.1016/j.cej.2011.02.042.

9. Dridi Gargouri O, Samet Y, Abdelhedi R. Electrocatalytic performance of $\mathrm{PbO} 2$ films in the degradation of dimethoate insecticide. Water SA 2013; 39(1): 31-8. doi: 10.4314/wsa.v39i1.5.

10. Hachami F, Errami M, Bazzi L, Hilali M, Salghi R, Jodeh $\mathrm{S}$, et al. A comparative study of electrochemical oxidation of methidation organophosphorous pesticide on $\mathrm{SnO} 2$ and boron-doped diamond anodes. Chem Cent J 2015; 9(1): 59. doi: 10.1186/s13065-015-0136-x.

11. Liotta LF, Gruttadauria M, Di Carlo G, Perrini G, Librando V. Heterogeneous catalytic degradation of phenolic substrates: catalysts activity. J Hazard Mater 2009; 162(2-3): 588-606. doi: 10.1016/j.jhazmat.2008.05.115.

12. Hosseini G, Maleki A, Daraei H, Faez E, Shahamat YD. Electrochemical process for diazinon removal from aqueous media: design of experiments, optimization, and DLLME-GC-FID method for diazinon determination.
Arab J Sci Eng 2015; 40(11): 3041-6. doi: 10.1007/s13369015-1798-3.

13. Ganzenko O, Huguenot D, van Hullebusch ED, Esposito G, Oturan MA. Electrochemical advanced oxidation and biological processes for wastewater treatment: a review of the combined approaches. Environ Sci Pollut Res 2014; 21(14): 8493-524. doi: 10.1007/s11356-014-2770-6.

14. Oller I, Malato S, Sánchez-Pérez JA. Combination of Advanced Oxidation Processes and biological treatments for wastewater decontamination--a review. Sci Total Environ 2011; 409(20): 4141-66. doi: 10.1016/j. scitotenv.2010.08.061.

15. Mohammadi L, Bazrafshan E, Noroozifar M, AnsariMoghaddam A, Barahuie F, Balarak D. Removing 2,4-dichlorophenol from aqueous environments by heterogeneous catalytic ozonation using synthesized $\mathrm{MgO}$ nanoparticles. Water Sci Technol 2017; 76(11-12): 3054-68. doi: $\quad 10.2166 /$ wst.2017.479.

16. Dadban Shahamat Y, Farzadkia M, Nasseri S, Mahvi AH, Gholami M, Esrafili A. Magnetic heterogeneous catalytic ozonation: a new removal method for phenol in industrial wastewater. J Environ Health Sci Eng 2014; 12(1): 50. doi: 10.1186/2052-336x-12-50.

17. Mohammadi L, Bazrafshan E, Noroozifar M, AnsariMoghaddama AR, Khazaei Feizabad AR, Mahvi AH. Optimization of the catalytic ozonation process using copper oxide nanoparticles for the removal of benzene from aqueous solutions. Glob J Environ Sci Manag 2017; 3(4): 403-16. doi: 10.22034/gjesm.2017.03.04.006.

18. Maddila S, Lavanya P, Jonnalagadda SB. Degradation, mineralization of bromoxynil pesticide by heterogeneous photocatalytic ozonation. J Ind Eng Chem 2015; 24: 33341. doi: 10.1016/j.jiec.2014.10.005.

19. Mosleh S, Rahimi MR. Intensification of abamectin pesticide degradation using the combination of ultrasonic cavitation and visible-light driven photocatalytic process: synergistic effect and optimization study. Ultrason Sonochem 2017; 35(Pt A): 449-57. doi: 10.1016/j.ultsonch.2016.10.025.

20. Hall S, Bradley T, Moore JT, Kuykindall T, Minella L. Acute and chronic toxicity of nano-scale $\mathrm{TiO} 2$ particles to freshwater fish, cladocerans, and green algae, and effects of organic and inorganic substrate on $\mathrm{TiO} 2$ toxicity. Nanotoxicology 2009; 3(2): 91-7. doi: $10.1080 / 17435390902788078$

21. Wang J, Bai Z. Fe-based catalysts for heterogeneous catalytic ozonation of emerging contaminants in water and wastewater. Chem Eng J 2017; 312: 79-98. doi: 10.1016/j. cej.2016.11.118.

22. Sánchez-Polo M, Leyva-Ramos R, Rivera-Utrilla J. Kinetics of 1,3,6-naphthalenetrisulphonic acid ozonation in presence of activated carbon. Carbon 2005; 43(5): 962-9. doi: 10.1016/j.carbon.2004.11.027.

23. Cataldo F, Putz MV, Ursini O, Angelini G. Surface modification of activated carbon fabric with ozone. Part 3: thermochemical aspects and electron spin resonance. Fullerenes, Nanotubes and Carbon Nanostructures 2016; 24(6): 406-13. doi: 10.1080/1536383x.2016.1172069.

24. Pratarn W, Pornsiri T, Thanit S, Tawatchai C, Wiwut T. Adsorption and ozonation kinetic model for phenolic wastewater treatment. Chin J Chem Eng 2011; 19(1): 76-82. doi: 10.1016/s1004-9541(09)60180-4

25. Tong S, Shi R, Zhang H, Ma C. Catalytic performance of $\mathrm{Fe} 3 \mathrm{O} 4-\mathrm{CoO} / \mathrm{Al} 2 \mathrm{O} 3$ catalyst in ozonation of 
2-(2,4-dichlorophenoxy)propionic acid, nitrobenzene and oxalic acid in water. J Environ Sci (China) 2010; 22(10): 1623-8. doi: 10.1016/s1001-0742(09)60298-9.

26. Ling W, Qiang Z, Shi Y, Zhang T, Dong B. Fe(III)-loaded activated carbon as catalyst to improve omethoate degradation by ozone in water. J Mol Catal A Chem 2011; 342-343: 23-9. doi: 10.1016/j.molcata.2011.04.005.

27. Dadban Shahamat Y, Sadeghi M, Shahryari A, Okhovat N, Bahrami Asl F, Baneshi MM. Heterogeneous catalytic ozonation of 2, 4-dinitrophenol in aqueous solution by magnetic carbonaceous nanocomposite: catalytic activity and mechanism. Desalin Water Treat 2016; 57(43): 2044756. doi: 10.1080/19443994.2015.1115372.

28. Ertugay N, Acar FN. Removal of COD and color from Direct Blue 71 azo dye wastewater by Fenton's oxidation: kinetic study. Arab J Chem 2017; 10(Suppl 1): S1158-63. doi: 10.1016/j.arabjc.2013.02.009.

29. Eaton A, Franson M. Standard Methods for the Examination of Water \& Wastewater. Washington, DC: American Public Health Association; 2005.

30. Rice EW, Baird RB, Eaton AD, Clesceri LS. Standard Methods for the Examination of Water and Wastewater. 23rd ed. Washington, DC: American Public Health Association; 2017.

31. Tizaoui C, Bouselmi L, Mansouri L, Ghrabi A. Landfill leachate treatment with ozone and ozone/hydrogen peroxide systems. J Hazard Mater 2007; 140(1-2): 316-24. doi: $\quad$ 10.1016/j.jhazmat.2006.09.023.

32. Norzaee S, Bazrafshan E, Djahed B, Kord Mostafapour F, Khaksefidi R. UV activation of persulfate for removal of penicillin $G$ antibiotics in aqueous solution. ScientificWorldJournal 2017; 2017: 3519487. doi: $10.1155 / 2017 / 3519487$.

33. Nawrocki J, Kasprzyk-Hordern B. The efficiency and mechanisms of catalytic ozonation. Appl Catal B Environ 2010; 99(1-2): 27-42. doi: 10.1016/j.apcatb.2010.06.033.

34. Yamamoto T, Kim SI, Chaichanawong J, Apiluck EA, Ohmori T. Removal of aqueous organic pollutants by adsorption-catalytic process using mesoporous carbon beads loaded with metal oxides. Appl Catal B Environ 2009; 88(3-4): 455-61. doi: 10.1016/j.apcatb.2008.10.011.

35. Lü X, Zhang Q, Yang W, Li X, Zeng L, Li L. Catalytic ozonation of 2,4-dichlorophenoxyacetic acid over novel Fe-Ni/AC. RSC Adv 2015; 5(14): 10537-45. doi: 10.1039/ c4ra11610k.

36. Lei L, Gu L, Zhang X, Su Y. Catalytic oxidation of highly concentrated real industrial wastewater by integrated ozone and activated carbon. Appl Catal A Gen 2007; 327(2): 287 94. doi: 10.1016/j.apcata.2007.05.027.

37. Beltrán FJ, Pocostales JP, Alvarez PM, Jaramillo J. Mechanism and kinetic considerations of TOC removal from the powdered activated carbon ozonation of diclofenac aqueous solutions. J Hazard Mater 2009; 169(1-3): 532-8. doi: 10.1016/j.jhazmat.2009.03.127.

38. Faria PC, Órfão José JM, Pereira Manuel FR. Activated carbon catalytic ozonation of oxamic and oxalic acids. Appl Catal B Environ 2008; 79(3): 237-43. doi: 10.1016/j. apcatb.2007.10.021.

39. Gonçalves AG, Órfão José JM, Pereira Manuel FR. Ceria dispersed on carbon materials for the catalytic ozonation of sulfamethoxazole. J Environ Chem Eng 2013; 1(3): 260-9. doi: $10.1016 /$ j.jece.2013.05.009.

40. Wu G, Jeong TS, Won CH, Cui L. Comparison of catalytic ozonation of phenol by activated carbon and manganesesupported activated carbon prepared from brewing yeast. Korean J Chem Eng 2010; 27(1): 168-73. doi: 10.1007/ s11814-009-0337-x.

41. Fan X, Restivo J, Órfão José JM, Pereira Manuel FR, Lapkin AA. The role of multiwalled carbon nanotubes (MWCNTs) in the catalytic ozonation of atrazine. Chem Eng J 2014; 241: 66-76. doi: 10.1016/j.cej.2013.12.023.

42. Akhtar J, Amin NS, Aris A. Combined adsorption and catalytic ozonation for removal of sulfamethoxazole using $\mathrm{Fe}_{2} \mathrm{O}_{3} / \mathrm{CeO}_{2}$ loaded activated carbon. Chem Eng J 2011; 170(1): 136-44. doi: 10.1016/j.cej.2011.03.043.

43. Wang Q, Yang Z, Chai B, Cheng S, Lu X, Bai X. Heterogeneous catalytic ozonation of natural organic matter with goethite, cerium oxide and magnesium oxide. RSC Adv 2016; 6(18): 14730-40. doi: 10.1039/c5ra21674e.

44. Nawaz F, Cao H, Xie Y, Xiao J, Chen Y, Ghazi ZA. Selection of active phase of $\mathrm{MnO} 2$ for catalytic ozonation of 4-nitrophenol. Chemosphere 2017; 168: 1457-66. doi: 10.1016/j.chemosphere.2016.11.138.

45. Trapido M, Veressinina Y, Munter R, Kallas J. Catalytic ozonation of m-dinitrobenzene. Ozone Sci Eng 2005; 27(5): 359-63. doi: 10.1080/01919510500250630.

46. Dhaouadi A, Adhoum N. Degradation of paraquat herbicide by electrochemical advanced oxidation methods. J Electroanal Chem 2009; 637(1-2): 33-42. doi: 10.1016/j. jelechem.2009.09.027.

47. Hu E, Shang S, Tao XM, Jiang S, Chiu Kl. Regeneration and reuse of highly polluting textile dyeing effluents through catalytic ozonation with carbon aerogel catalysts. J Clean Prod 2016; 137: 1055-65. doi: 10.1016/j.jclepro.2016.07.194.

48. Tehrani-Bagha AR, Mahmoodi NM, Menger FM. Degradation of a persistent organic dye from colored textile wastewater by ozonation. Desalination 2010; 260(1-3): 348. doi: 10.1016/j.desal.2010.05.004.

49. Ghahrchi M, Rezaee A. Electro-catalytic ozonation for improving the biodegradability of mature landfill leachate. J Environ Manage 2020; 254: 109811. doi: 10.1016/j. jenvman.2019.109811.

50. Poyatos JM, Muñio MM, Almecija MC, Torres JC, Hontoria E, Osorio F. Advanced oxidation processes for wastewater treatment: state of the art. Water Air Soil Pollut 2009; 205(1): 187. doi: 10.1007/s11270-009-0065-1.

51. Sui M, Sheng L, Lu K, Tian F. FeOOH catalytic ozonation of oxalic acid and the effect of phosphate binding on its catalytic activity. Appl Catal B Environ 2010; 96(1-2): 94100. doi: 10.1016/j.apcatb.2010.02.005.

52. Wang Y, Xie Y, Sun H, Xiao J, Cao H, Wang S. 2D/2D nano-hybrids of $\gamma-\mathrm{MnO} 2$ on reduced graphene oxide for catalytic ozonation and coupling peroxymonosulfate activation. J Hazard Mater 2016; 301: 56-64. doi: 10.1016/j. jhazmat.2015.08.031.

53. Cortez S, Teixeira P, Oliveira R, Mota M. Ozonation as polishing treatment of mature landfill leachate. J Hazard Mater 2010; 182(1-3): 730-4. doi: 10.1016/j. jhazmat.2010.06.095. 